\title{
Facilitating the Energy Transition-The Governance Role of Local Renewable Energy Cooperatives
}

\author{
Donné Wagemans *, Christian Scholl * (D) and Véronique Vasseur * \\ International Centre for Integrated assessment and Sustainable development (ICIS), P.O. Box 616, \\ 6200 MD Maastricht, The Netherlands \\ * Correspondence: d.wagemans@alumni.maastrichtuniversity.nl (D.W.); \\ christian.scholl@maastrichtuniversity.nl (C.S.); veronique.vasseur@maastrichtuniversity.nl (V.V.); \\ Tel.: +31-(0)-43-3882659 (C.S.)
}

Received: 30 September 2019; Accepted: 31 October 2019; Published: 1 November 2019

\begin{abstract}
The governance role of local renewable energy cooperatives (LRECs) in facilitating the energy transition remains under-scrutinized in the scholarly literature. Such a gap is puzzling, since LRECs are a manifestation of the current decentralization movement and yield a promising governance contribution to a 'just energy transition'. This paper presents a study of the governance roles of LRECs in the province of Limburg, the Netherlands. Building on existing work on the cooperative movement and energy governance, we, first, develop a conceptual framework for our analysis. The framework is built around three key interactions shaping these governance roles, between (1) LRECs and their (potential) members, (2) LRECs and the government and (3) LRECs with other LRECs. The results of an online survey and qualitative interviews with selected cooperatives led to the identification of five key governance roles that these cooperatives take up in the facilitation of the energy transition: (1) mobilizing the public, (2) brokering between government and citizens, (3) providing context specific knowledge and expertise, (4) initiating accepted change and (5) proffering the integration of sustainability. The paper concludes by reflecting on the relevance of our findings in this Dutch case for the broader 'just transition' movement.
\end{abstract}

Keywords: energy transition; local renewable energy cooperatives; governance roles; citizen participation; mixed methods

\section{Introduction}

Community action and involvement in the transition towards a society based on sustainable renewable energy has increased significantly during the last decade, leading to changes in how energy systems are integrated into societies around the world [1]. Spurred not least by concerns about the negative effects of fossil fuels which pollute the biosphere, reinforce the greenhouse gas effect in the atmosphere and upset the balance of the hydrosphere. As opposed to traditional fossil fuel based energy, renewable energy (RE) originates from naturally replenished resources such as sunlight, wind, rain, tidal movements and geothermal heat [2]. Similar to many other European countries, the Netherlands has recently experienced the emergence of local renewable energy initiatives. These initiatives are community efforts that mean to transform the energy sector to make it more decentralized, democratic and sustainable [3-5]. A distinct type of a community effort is the Local Renewable Energy Cooperative (LREC). In recent years, cooperatives have been created to promote the use of renewable energies, most notably in Canada [6], the United Kingdom [7], Denmark [8], Belgium [9] and Germany [10]. Cooperatives are autonomous associations of citizens who collaborate voluntarily to meet their common economic, social and cultural needs and aspirations through a system of businesses that are jointly owned and democratically controlled [2]. 
As the energy industry is getting more diverse and decentralized these LRECs are one of the visible ongoing developments. By integrating equity and other concerns, they carry the additional potential of contributing to a 'just (energy) transition,' which according to recent scholarship transcend established concerns of a 'energy transition' [11]. Following the well-known concept of cooperatives which emerged in the United Kingdom in the 19th century [12], LRECs empower citizens outside the energy industry with the opportunity to bundle resources to implement renewable energies while also participating in cooperative energy consumption. As renewable energy is becoming increasingly relevant in many countries, LRECs are gaining ground. For instance, the European Federation of Renewable Energy Cooperatives (REScoop) represented 1240 LRECs in 2018 with a total of 650,000 European citizens as members. Given this remarkable success of LRECs, it is expedient to find out how the governance of and by these cooperatives plays a role in the facilitation of the energy transition [13].

Bauwens [9] researched the cooperative energy movement in Flanders, specifically investigating the role of cooperative members and the heterogeneity of their motivations and the implications this has on their level of engagement. He concluded that while cooperative members are often considered as one homogenous group, several categories of members with differing motivations and levels of participation can be distinguished. Our research did not include the perspective of the cooperative members as Bauwens did. Therefore, the identified governance roles only reflect the perspective of the cooperative board. It is suggested that future research will also include the perspective of the cooperative members to verify the identified governance roles.

Research conducted by Hoicka and MacArthur [6] investigated community energy projects within Canada and New Zealand. More specifically focusing on the participation of indigenous people. Their research investigated the role of incumbent resources, actors and the political environment to investigate the differing functions of community energy initiatives. Their research concluded that community energy initiatives play an important role in overcoming challenges of uneven economic development, inequality and fuel poverty similar to the results of our research in Limburg. These issues are especially prevalent in countries with a colonial history which differs it from the Netherlands. There are however similarities between the role of LRECs in peripheral areas such as Limburg and the uneven economic development and inequalities mentioned by Hoicka and MacArthur in rural communities within Canada and New Zealand.

While our research took a specific focus on the Dutch experience of the governance of energy transition, it can be seen within the wider movement of the democratization of energy and a just energy transition. This movement calls for more participatory forms of energy provisions, including local autonomy over energy in decentralized systems such as seen in LRECs. Energy cooperatives are expected to play a strong part in this movement as they are owned and managed by the members of their members and reflect the priorities of their communities as indicated by Stephens [14]. The identified governance roles found within this research align with these expectations for LRECs as they partially reclaim the energy infrastructure shifting toward more direct community-level economic benefits. At the same time, they contribute to the democratization movement by moving away from interests that concentrate wealth and power

In 2018 the Netherlands counted 484 energy cooperatives, an increase of 20\% compared to 2017 [15]. Almost 70,000 citizens are currently a member of such a cooperative. The generally defined goal of these local renewable energy cooperatives is to involve citizens to participate in practices concerning energy saving, production and trade, with the proceeds of these activities flowing back to the local community as much as possible [15]. These efforts are vastly different from the status quo practices which often involve large energy providers with little to no connection to the local community. In many cases renewable energy projects will therefore experience resistance by local community members as they experience negative externalities of these projects and are not actively involved in the project themselves nor do they share in the benefits [16,17].

Similar to the rest of the Netherlands, the province of Limburg is in the process of working towards the energy transition in an attempt to contribute to the efforts set forth in the Paris Agreement 
to limit global temperature rise to well below $2{ }^{\circ} \mathrm{C}$ as compared to pre-industrial levels. In order to reach this goal, all the signatory parties including the Netherlands pursue a shift toward low carbon economies with a focus on using renewable energy sources, reducing energy demand and increasing energy efficiency levels. In specific terms the Netherlands as part of the European Union is committed to a 'binding target of an at least $40 \%$ domestic reduction in greenhouse gas emissions by 2030 as compared to 1990' [18]. As stated in the Nationally Determined Contribution of the EU and its Member States. This includes the effort to reduce energy emissions which has been described as the low carbon energy transition [19]. Additionally, the European Commission's RED II directive came into force in November 2016. This directive sets an overall target of 32\% renewable energy consumption by 2030 . RED II mentions activities of individual and collective self-consumption through renewable energy communities such as LRECs to collectively facilitate local participation in the energy system and attain the set targets [20].

Energy Cooperatives in Limburg have been supported by the Natuur en Milieufederatie Limburg (NMF), the Nature and Environmental Federation Limburg, since 2012 through the Servicepunt Energie Lokaal Limburg (SELL). SELL is a service centre that aims to support energy initiatives in order to accelerate the energy transition [21]. After the first cooperative initiatives were started, local projects soon began to take shape with the first cooperative wind turbine being built in Limburg in 2015 and five more in the works. Additional solar projects have been sprouting up in multiple municipalities as well. According to the national energy monitor 'HIER opgewekt' (Dutch for "generated here"), the future of local energy cooperatives in Limburg is looking very promising as there are relatively few objections and short lead times. This resulted in an almost 35\% growth of energy cooperatives in 2018 where the number of energy cooperatives in Limburg increased from 13 to 20 [22]. Therefore, Limburg provides a promising environment for researching the governance by LRECs.

As of 2017, there are multiple LRECs in Limburg with more than a hundred members generating revenues exceeding $€ 100,000$. The cooperatives have plans to have a combined capacity of more than $70 \mathrm{MW}$ within the near future together, aiming to circulate profits within the local community, support social goals and promote the liveability of small local communities [23]. These are ambitious goals. However, the feasibility of these goals will depend on whether the cooperatives can successfully facilitate the governance of the energy as well, as bad governance practices which could potentially smother the potential of LRECs [24].

In this paper, LRECs are analysed from a governance perspective. Thereby, we build on recent attempts by scholars who have started to scrutinize governance processes in community energy projects [7] and mapped legal governance issues of energy sector innovations by community energy services [5]. By studying LRECs in Limburg, we want to get to know in which ways local renewable energy cooperatives contribute to the renewable energy transition from a governance perspective. We conceive of governance as the process of steering society and the economy through collective action and in accordance with common goals [25]. More specifically certain dimensions of the 'governance paradigm' include: inclusion of institutions and actors from and beyond government; blurring roles and responsibilities; power dependence in relationships between institutions, autonomous self-organising networks of actors; and, governing with new techniques to steer and guide, rather than utilising command or authority [26]. By studying the role LRECs play in governance, we want to find out what their actual contribution is to the governance of the energy transition, how this contribution is hampered and how it could be amplified. Despite deeper insights in the governance roles taken up by LRECs, we also expect the results to contribute to give LRECs a better and more reflected place in the overall governance of the energy transition. While our research placed a specific focus on the Dutch experience of LREC governance the results will also be discussed in the wider context of the (energy) democratisation and 'just transition' movement.

For this research, governance is studied by analysing it at a more concrete level of three interactions between an LREC and other parties reflecting the polycentric environment of power in which they operate, as indicated by Meadowcroft [27]. This environment is characterized by power 
being decentralised and distributed to different groups who collectively determine the direction of developments. The first relationship is that of the LREC and its members (a) for example, opportunities for member input, the second of the LRECs amongst each other (b) for example, utilization of knowledge sharing opportunities, the third is the relationship between the LREC and the government (c) for example, regularity of meetings with city councils. These relationships are displayed in Figure 1.

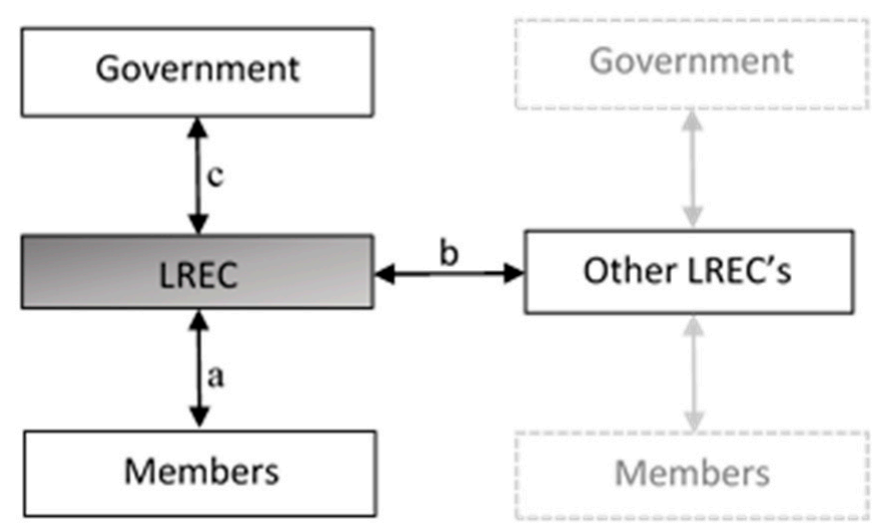

Figure 1. Key governance relations $(a, b, c)$ that are the focus of the proposed research (authors' own).

\section{Research Design and Methods}

The first phase of the research consisted of a literature review. First, a search for several key words regarding energy cooperatives and local energy initiatives were submitted to online academic databases such as: EBSCO, Web of Science, JSTOR, Scholar, Sage and Springer in search of relevant, peer-reviewed and timely articles with a focus on the European context of energy cooperatives. Based on the popularity of these articles as determined by the number of references, several articles where selected for the initial preparatory study. Second, by following up on key concepts, frequent authors and referred grey literature found in the initial study, a more extensive body of literature was created. The cumulative result of this study was the identification of several key governance dimensions that are relevant for local renewable energy cooperatives.

In the second phase of the research, the key dimensions of the LRECs within Limburg were investigated through an online survey created using the Qualtrics software for collecting and analysing data online. The online survey started with several short questions inquiring about general data on the cooperative, including amongst others the focus, the years of operation and the number of members. The data collected was helpful for having a general overview of the energy cooperatives in Limburg. In addition, the survey investigated the different governance dimensions and their importance for the cooperative. Respondents were able to provide answers on a 5-point Likert scale ranging from 'not at all important' to 'very important' [28]. The option 'not applicable' was included to prevent respondents having to choose a level of agreement for statements that do not apply to their case. The score was then used for the typology development.

There are several advantages of utilizing the Likert scale. First, the responses are easily quantifiable. Second, respondents are not forced to take a definite stand on a particular topic but to respond in a degree of importance. This is supposed to make answering easier for the respondent. Third, the responses accommodate neutral or undecided feelings on importance. Because of these reasons, the Likert scale offers a quick, efficient and suitable method for data collection [29]. The survey was distributed to all 23 known cooperatives in the province of Limburg. This led to 11 distinct responses from 11 different cooperatives. The response rate was $43 \%$. We wanted as many cooperatives as possible to answer the survey to have an extensive amount of data available for the typology development. Preferably, the cooperatives should have different focusses, sizes, locations and years of operation.

In the third phase and based on the survey results, a typology has been developed in two steps. First, the survey data was analysed to identify the greatest polarity of responses. If cooperatives 
provide vastly different answers regarding the importance of a particular governance dimension, this could indicate that this dimension is suitable for typology development. If respondents indicate very similar preferences for one of the governance dimensions, this could indeed be a very important dimension but was not considered suitable for differentiating amongst the cooperatives. Out of the most polarizing governance dimensions indicated by the widest response ranges, two have be selected as the main variables for the typology development.

As the answers the respondents corresponded to an interval scale, an average score could be calculated for the two determining governance dimensions. These scores will correspond to a coordinate on an $\mathrm{x}$-and $\mathrm{y}$-axis. Resulting in a scatterplot indicating the positions of each individual LREC and the degree to which they fit into a certain type. This allowed for a clear and simple overview of the distribution of the research population as well as a straightforward indication of the most deviating cases, which qualified for further inquiry through interviews.

The fourth phase of the research consisted of two separate (group) interviews with five senior controlling cooperative members of two distinct cooperatives. The interviews were performed in a semi-structured format and inquired about the cooperatives and their different governance interactions at an in-depth level. The semi-structured format allowed the interviews to unfold in a conversational manner, offering the interviewees the chance to pursue issues they feel are important [30]. Interviews lasted ca. $90 \mathrm{~min}$ and, were audio-recorded and summarized afterwards. Four distinct LRECs were selected for follow up interviews based on the results of the survey and additional information they provided. As selection criteria, the cooperatives either had the most extreme scores in their respective category, were surprising outliers or they provided information indicating interesting governance perspectives which required further investigation. Out of the four selected cooperatives two agreed to an interview. These were Duurzaam Roerdalen and Duurzaam Maasgouw, established in 2017 and 2018, respectively. Both cooperatives are relatively young each having less than 100 members.

\section{Governance by Local Energy Collectives}

In order to identify the key dimensions that are relevant for analysing governance by local renewable energy cooperatives, we reviewed the literature of the two fields of energy governance and cooperative movements. During this search, we identified key dimensions for the analysis of the role of cooperatives in energy governance. These are: participatory practices, democratic decision making, mobilizing capacity, professionalization, legitimacy, collaboration with governmental institutions, support networks and the policy context. Each of them is briefly outlined below. For our analytical framework presented at the end of this section, these dimensions are then grouped together under the three key interactions of cooperative governance.

\subsection{Participatory Practices}

Participation is one of the key elements of environmental governance that contributes to better decision making $[27,31]$. It is recognized that issues regarding sustainability require the involvement of the public. Participation provides this link between the public and the governance of the energy transition in this instance. A strong public participation in environmental governance increases the commitment among stakeholders by providing a stronger sense of ownership. When stakeholders are allowed to voice their opinions and insert them into a project, this strengthens their belief in the cooperative project as well as fostering increased acceptance of any measures taken. An example is the increased acceptance of wind turbines if they are managed through participatory citizen initiates such as cooperatives [7]. In addition, some argue that the right to participate in matters concerning the protection of the environment such as the phasing out of fossil fuels for renewable energy, is a procedural right that should be considered as incorporated in the fundamental right to environmental protection [31]. From this perspective, governance of the energy transition is expected to operate by a framework of fairness, inclusivity and equality, which calls for the engagement of the public. 
Yet, participation can take many forms, as already indicated by Arnstein [32] when she devised the participation ladder for the level of citizen involvement in government decision making. This ladder ranges from full scale citizen power (or member power when translated to cooperatives) trough forms of tokenism to nonparticipation. While the top rungs of the ladder indicating citizen power would be more in line with the cooperative movement philosophy, empirical testing might reveal disparities amongst the different energy cooperatives in Limburg.

\subsection{Democratic Decision-Making}

Participatory practices are closely linked to the way in which energy cooperatives organize internal democracy. Democratic control is one of the seven principles of the cooperative movement [33]. It is defined as the governance of an organization by its members through majority decision-making. The cooperative movement as a general rule employs the rule of ' 1 member $=1$ vote' this eliminates the possibility that members with higher investments trump the decisions, leaving members with a smaller investment without decision making power [33].

In cooperatives, internal democracy includes consideration of rights and corresponding responsibilities. It also encourages the fostering of a "spirit of democracy" [33] within the cooperative. This spirit of democracy has proven to be a challenging task but it is considered to be socially valuable and essential. The major benefit is that it contributes to deepening democratic roots within civil society.

It is important that it is recognized that a democratic process, in itself, is no guarantee for competence. A fundamental characteristic of sustainable democratic systems is that democracy requires the protection of sound governance codes, democratic laws procedures and processes, similar to formalized models of organization management. Organizing internal democracy can be considered a key dimension of cooperatives. Cooperatives tend towards deliberative and participatory forms of democracy with constant engagement of members in day-to-day decision making according to the cooperative principles. Members are involved in proposing and approving fundamental strategic policy decisions and able to hold elected representatives on boards or committees and senior executives to account. One of the biggest challenges facing cooperatives is creating a culture that accepts and encourages debate rather than stifling it. Debate should be seen as a sign of a healthy democracy that encourages members to become an active part of the cooperative [33,34].

Cooperatives can take advantage of technological developments. Especially advances in modern mobile as well as internet communication make it easier to actively engage members in the democratic process of the cooperative [33].

\subsection{Mobilizing Capacity}

According to the European Commission [35] citizens are at the core of the energy transition. Citizens should take ownership of the transition, benefit from new technologies to reduce their bills, participate actively in the market and be protected when vulnerable. Since the European market is transforming from a centralized market dominated by large utilities to a decentralized market with millions of citizens that are active or prosumers, citizen involvement in the energy transition becomes more likely [35].

Cooperatives allow in different ways for the mobilization of citizens for investment in sustainable energy and for projects where energy is provided by citizens. Renewable energy cooperatives have transformed the energy landscape in many European countries while also consequentially contributing to revitalizing local economies and creating local jobs [36]. These mobilized energy communities deliver a significant share of renewable energy investments, promote local development and increase public support of renewable energy. For example Germany, where renewables deliver $40.4 \%$ of the country's electricity [37]. Nearly every second $\mathrm{kWh}$ of this renewable electricity is generated by a broad range of citizen initiatives. Therefore, it revitalizes the local economy while also generating jobs within the local domain [36]. 


\subsection{Professionalization}

The increasing scope and scale of cooperative projects has led to a trend of growth and a desire for professionalization in the Dutch cooperative energy section. Elzenga and Schwencke [38] indicate a clear wish among community initiatives to professionalize. There is a shift from providing energy saving services to more ambitious projects of energy production. According to Hermans and Fens [39], there is an increase in projects that include the actual supply of electricity. Thereby, cooperatives become electricity producers and take a role in service provision.

Almost two thirds of the cooperatives situated in the Netherlands deliver electricity to their members and customers through a resale construction. However, two recently founded cooperatives have taken this supply function to a new level. The cooperatives NLD and DE Unie, established respectively in 2013 and 2014, did acquire a supplier license. This enables them to act as an electricity utility and purchase electricity on the wholesale market to provide to its customers. The members of these two cooperatives are existing local wind and energy cooperatives who now no longer require mediation of a conventional commercial energy company to supply electricity to their members [40].

In order to obtain a supplier license, the cooperative has to comply with a list of stringent rules and regulations. This includes conditions set by the Consumer \& Market Authority [41]. In order to comply with these regulations, a high level of organizational, financial and technical expertise are required for the cooperatives to meet their legal obligations for supplying electricity. Therefore, the acquirement of a supplier license by these two cooperatives forms an adequate illustration of the ongoing professionalization across energy cooperatives [40].

However, this trend towards professionalization does not apply to every cooperative as not all cooperatives have the ambition to increase the scope or scale of their projects. Seyfang, Park and Smith [42] state that 'although some groups do have ambitions to expand and grow, others are simply providing local solutions to local needs as an end in itself and have no desire to expand' (p. 988). This appears to be the case for the Netherlands, where scholars identified a tension between the small-scale idealists who prefer local small-scale solutions and the more commercially oriented cooperatives who would like to scale up local renewable energy projects [43].

The degree of professionalization is a relevant governance dimension as it is an indicator as to how far citizen initiatives take over utility services formally managed by either public governments or private businesses, indicating a blurring roles and responsibilities which are a key aspect of governance.

\subsection{Legitimacy}

The International Co-operative Alliance's (ICA) Guidance Notes on the Cooperative Principles state that openness, transparency and accountability are important for good democratic governance [33]. These three concepts are grouped together according to the ICA's approach, as they are firmly related to each other with effects on one having immediate impacts on the others. Together these three concepts reflect a sense of trust and legitimacy of the LREC. According to the ICA these three concepts are essential for any cooperative to be legitimate and thus effective [33]. Cooperatives should make agendas and write down minutes of meetings of their elected committees and boards. These should become available to members. However, there are types of information that cannot easily be shared openly. This could be because of commercial sensitivity, regulatory requirements or respect for employee privacy. However, within these limitations cooperatives should ensure that members have the opportunity to debate and hold the board accountable for decisions. Elected representatives should present regular statements of account, financial reports and performance reports to their members. These should be presented in such a way that it is understandable for laypeople [33].

Since democratic member control is a key differentiating characteristic of cooperatives in comparison to conventional investor or shareholder-owned businesses, cooperatives should aspire to be open, transparent and accountable. This increases trust and legitimacy which is key for the success 
of the cooperative [44]. The democratic practices of an energy cooperative should be subject to critical assessments which can be achieved through cooperative-specific audits [33].

\subsection{Collaboration with Governmental Institutions}

Local renewable energy cooperatives collaborate with multiple governance levels and in multiple ways. Common amongst these is a collaboration through knowledge sharing at the local to regional level [45]. Cooperatives could be key in assisting municipalities to switch towards renewable energies. Yet, municipalities are often reluctant to work together with cooperative solutions initiated by citizens. In turn, many cooperatives are unsure about what to expect from municipalities. Even so, there seems to be a strong desire amongst both parties to find a way to work together while as of now they are still unsure about how this should happen [45].

Collaboration with cooperatives yields advantages for regional and local governments. Energy cooperatives have proven to be effective at mobilizing citizens in energy production and saving solutions. This indicates an opportunity for taking large steps towards the energy transition. One example of such a cooperation is the municipality of Haarlem. In this city there are five jointly managed roofs with solar PV installations, resulting in a combined amount of ca. 2000 solar PV panels [45]. According to the municipal policy makers in Haarlem, people who have been actively involved with citizen led energy initiatives will experience a lasting sustainability effect. This mindset could be key for meeting the national climate targets [45]. Haarlem is therefore a good example for collaboration between local governments and energy cooperatives.

Cooperatives, on the other hand, can also benefit from collaboration with local and regional governments. An example is the Leudal Energie cooperative, which initiated a project to change thousands of traditional lightbulbs within their community to more energy efficient LED-lights. In addition, they operate two solar PV stations on the roofs of local schools and are working on a local wind turbine. The Leudal Energie board indicated that the municipality is of great help when it comes to realizing these projects [45].

Collaboration with governmental institutions is not only about securing additional funding. The network that becomes available through collaboration can be as valuable as financial assistance. The Leudal Energie cooperative, for example, started working together with local housing cooperatives through mediation by the municipality. The municipality also assisted in the search of suitable fields for solar installations and offered the roof of the city hall for solar developments. Finally, the municipality contributes to the outreach of the cooperative by communicating successes on their website and to local newspapers [45].

The support from the community and other actors is an important dimension for cooperatives. On the local level, support from local residents and other local organizations such as schools, sports associations and community centres, create vital opportunities for cooperatives to find members as well as a strong basis for developing projects. Local businesses also form important partners. Shops, local installation businesses, restaurants or farms all provide valuable additions to a cooperative network [46]. Additionally, cooperatives also work together with larger commercial parties such as energy providers, for example, by reselling the electricity from an energy company to the cooperative members through resale construction [40].

On the other hand, a lack of community support or a limited network of other actors can cause great challenges for a cooperative. The absence of local resident support could result in public apathy, the NIMBY-effect ("Not in My Back Yard") and other forms of community resistance [47]. Even if cooperatives have the intention to generate benefits for the local community, this does not convince all residents and could even be regarded by some as bribery $[17,38]$. This can be illustrated by the case of the Energie- $U$ cooperative in Utrecht. The cooperative worked in commission of the municipality on the development of a wind farm near the city for almost two years before the project was cancelled. The city council decided against the wind farm due to strong local resistance, which indicates the impact of the absence of local support for the success of cooperatives $[38,48]$. 
Strong support networks are thus of key importance for energy cooperatives. Not only on the local but also on the regional, national and international level, cooperatives provide and receive help from a range of organizations. Many energy cooperatives work together with other cooperatives to form a supportive network. An example of this is the REScoopNL network, which aims to support renewable energy cooperatives to make them successful [49]. These networks provide a knowledge sharing and mutual learning environment by providing 'distinctive expertise that is not readily available elsewhere' [50] (p. 4403). Networks also have the added benefit of allowing for a joint lobby force in cooperation with other initiatives [43].

The REScoop organization is also active at the European level. With a network of 1500 European renewable energy cooperatives, representing a combined 1,000,000 citizens REScoop wishes to empower citizens to achieve energy democracy by representing their voice, supporting start-up cooperatives, providing services and promoting the LREC business model. REScoop promotes collaboration amongst European cooperatives [51]. Cooperative networks are thus active from the regional to the international level.

\subsection{Policy Context}

The context in which energy cooperatives operate is shaped by government regulations and therefore forms an important dimension for their analysis. There is a wide body of laws, policies and regulations that together form the regulatory and policy context or as titled by Bakker [40] the 'rules of the game.' These are the conditions under which the interaction between LRECs, their members, society and the wider governance system takes place.

Navigating along these rules can be tough for cooperatives as the current electricity law in the Netherlands dates back to 1998 and therefore is often unsuited for these changes in the energy system. The main structure of the law has remained unchanged and although several amendments were made throughout the years current rules and regulations do not always seem to be equipped to handle the rapidly changing role of civil actors in the energy market. This is especially true for community energy actors such as cooperatives who produce their own electricity, as this means that the consumer will operate within the regulated domain [40,52]. Dutch law dictates that each consumer needs to have an energy company that is, a party with a supplier license, to cover their electricity demand. However, as the term "prosumers" [53] suggests, a growing number of previous consumers in the electricity supply chain are now also producers, by taking part in a small energy company next to buying energy. In the Netherlands, it is still challenging for consumers to acquire a license needed to legally fulfil the supplier role. As indicated before, some energy cooperatives manage to obtain such a license. This requires a highly professionalized organization of the cooperative, which is often challenging for citizen's initiatives and may come with adverse effects concerning internal democracy.

The policy context also is critical where it comes to the amount of taxes consumers pay for electricity. In the Netherlands, individual producers generating their own electricity are exempted from this tax through feed-in tariffs. Where producers of electricity receive around six to seven eurocents for each $\mathrm{kWh}$ produced, the consumers pay roughly 20 eurocents for each $\mathrm{kWh}$ [40]. The difference is caused by distribution costs and taxes. When a consumer has a solar panel that produces electricity, they can deduct the produced energy from their total energy bill [54]. This saves roughly 20 cents per $\mathrm{kWh}$ of electricity generated by the solar panel, as this electricity is for direct use and not distributed through grid. On the other hand, if solar panels produce more than the users demand, the excess electricity is compensated with six or seven cents per kWh [54]. Up until 2016, it was legally impossible to generate energy anywhere outside of your personal, privately owned property. This was challenging for energy cooperative as due to these regulations they had to base a profitable business plan on the low six to seven cent rate. This has changed since 2016 with the introduction of the 'postcoderoos' (Dutch for 'zip code area arrangement') postal code regulation, providing more room for LRECs [40]. The 'postcoderoos' regulation provides a tax rebate which gives members of an energy cooperative a discount on their energy bills. If consumers invest in the generation of renewable energy within their 
area, they have a right to this rebate. The condition is that participants have to live within certain nearby postal zones of the project. Participants may only use a maximum of 10,000 kWh/year [55].

Multiple cooperatives in the Netherlands have also been pushing for self-delivery (e.g., NLD and $D E$ Unie). This is the direct delivery of power to their members without having an energy company working as an intermediary. Thereby, cooperative members can avoid VAT and energy taxes. The institutional framework forms a barrier in this case as self-delivery is against the rules of the game and is not allowed under the current legal framework [54].

These rules of the game are of vital importance to the local renewable energy cooperatives as decisions made at higher government levels-over which they have little to no say- could create opportunities for energy cooperatives or, conversely, limit their ability to operate. Therefore, we consider the "rules of the game" a critical dimension for the analysis of the governance by energy cooperatives. In recent developments, however, cooperatives have been increasingly involved in the development of policy, indicating a blurring line between the roles of citizens and governments in shaping the energy transition [56].

\section{Analytical Framework for Studying Governance by LRECs}

In order to analyse the governance by LRECs and their influence of the facilitation of the energy transition key interactions between LRECs and respectively, their members, government and other LRECs were identified. Figure 2 works out the three key interactions of LRECs-with their members, other LRECs and governments-in a more detailed way integrating the dimensions identified in the literature review above. This figure served as analytical framework for this article and guided the analysis of the research data. Whereas we do not want to claim that this conceptual framework is an exhaustive and perfect representation of all the complex governance interactions that LRECs engage in, we believe that it sufficiently specifies the dimensions that are relevant for an analysis of their governance roles. The analytical framework also guided our development of a typology of LRECs which can serve to structure future comparative research into these governance roles.

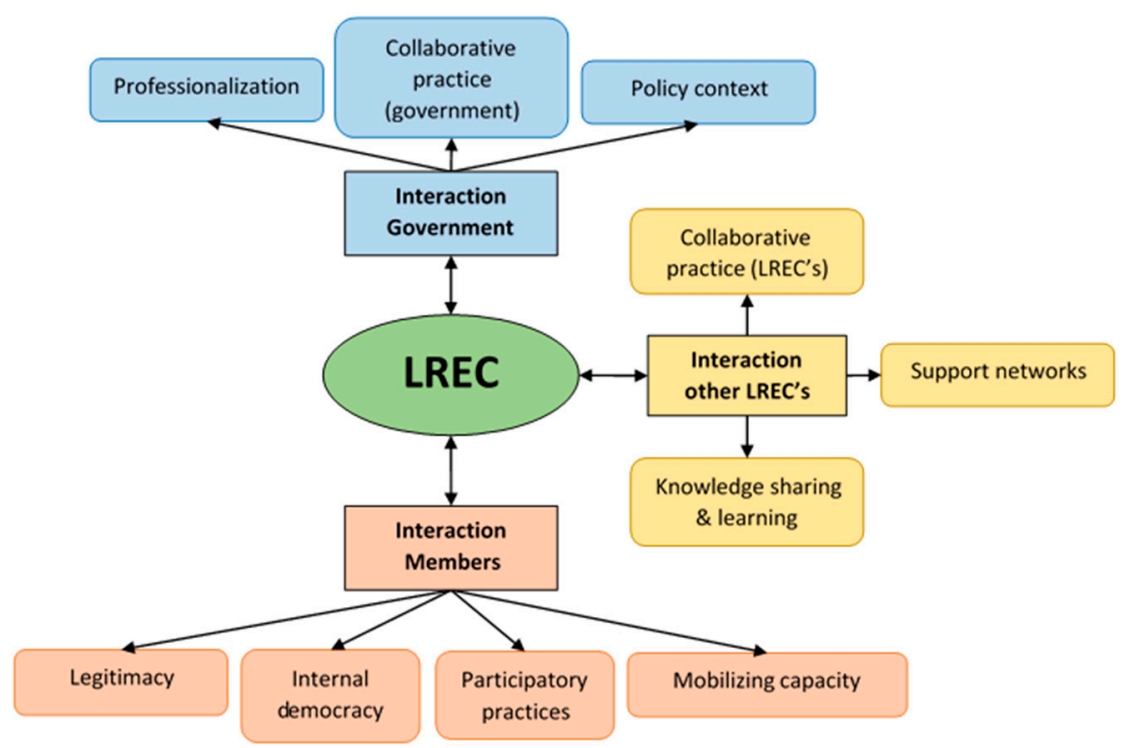

Figure 2. Conceptual framework of local renewable energy cooperative (LREC) interactions and governance dimensions.

The framework can be explained as follows. There are three main interactions between local renewable energy cooperatives and other governance actors, similar to the upwards, downwards and sideways interactions as indicated by Meadowcroft [27]. First, there is the upward interaction between members and the LREC. Here the members of the cooperative steer the cooperative through collective action. The LREC itself is however still in control. Similar to how citizens steer the state through a 
representative democracy while the state is still the official source of legitimate power, LRECs are controlled by their members who are represented in the board. Thus, this reflects a form of sub-level governance. Here, key dimensions are-democracy, participation, openness, transparency and accountability and the mobilization of communities. Secondly, the LRECs also cooperate with each other through sideways interactions such as collaboration, knowledge sharing practices and networks through a set of different governance dimensions that operate at the meso-level. These reflect the interaction amongst LRECs. This interaction is very similar to cooperation between cities in city networks such as found in conventional governance literature $[57,58]$. Third, there is the downward interaction at the macro-level between LRECs and the state. These interactions are characterized again by collaboration-which now represents collaborative efforts between cooperatives and the state, professionalization and the rules of the game reflecting the entire law and policy environment in which the LRECs operate.

The conceptual framework served as a visual tool initially with the purpose to assist in the design of the interview grid, which covered all these different dimensions of interactions. During the interview phase, these interactions where the main thread that guided the semi-structured interviews, thereby ensuring that the cooperatives could discuss all the three interactions in more depth with a focus on their governance roles.

\section{Towards a Typology of LREC Governance}

Based on the data collected from the surveys, we attempted to develop a typology of differentiation. In order to determine the two key characteristics to be used for typology development, the variables with the biggest range amongst respondent answers are of importance. If the range is rather large, this means that respondents have given vastly different answers within this group. If the cooperatives provide different answers, this is interesting for typology development as it indicates that the cooperatives differ on this area. Hence, this approach employs diversity as the guiding principle for selecting the two analytical dimensions.

The two groups with the widest difference in responses were the categories "collaboration" and "ambition" and therefore served as the central axes for the typology development. Any other combination of two variables would have resulted in a less clear delineation between the cooperatives of this dataset. "Collaboration" reflects the degree to which cooperatives wish to collaborate with other cooperatives and government institutes. "Ambition" reflects the difference between cooperatives preferring small scale projects with a local impact and those which would like to have a larger scale impact. When these two variables are plotted against each other (see Figure 3), the following observations can be made. Almost all cooperatives are located in the important/important quadrant of this figure. Only one cooperative is located in the not important/important quadrant. However, this cooperative is still located rather close to the median of the collaboration axis, indicating that cooperation is still somewhat important. Therefore, based on this figure no clear typologies can be developed as that would require the cooperatives being spread out more across the four quadrants and ideally more towards the extremes of these quadrants.

Therefore, based on the available data no sufficient evidence for the creation of different governance typologies can be identified. Fortunately, the survey data revealed several other interesting issues, which helped to guide the further research on LRECs governance roles. It is however recognized that a sample of 11 cooperatives is rather small and therefore there is a large chance of making a Type II Error where the cooperatives were actually different but it is concluded that they are not [59]. Additionally, there could be sub-forms of clustering that could provide relevant outcomes for devising typologies. For example, the ambitions variable could be divided in a material and idealistic aspect and the collaboration in institutionalised and ad hoc aspect. However, based on the data provided by the conducted survey no such conclusions can be drawn and the usefulness of this typology will have to be determined by future studies. 


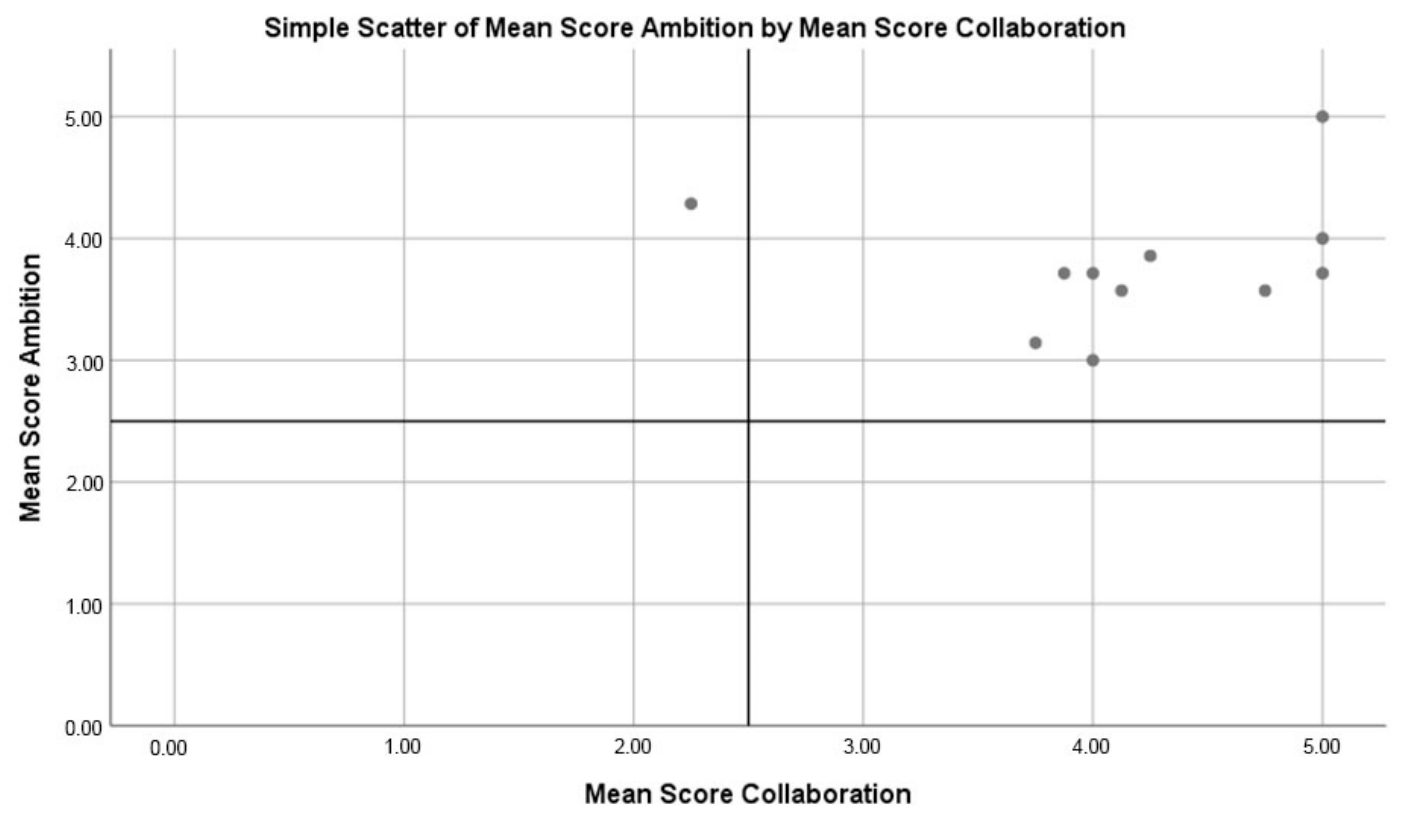

Figure 3. Scatterplot of cooperatives by collaboration and ambition characteristics.

\section{The Five Governance Roles of LRECs}

In this section the results of the empirical research are synthesized. First, we discuss the five key governance roles of the researched cooperatives: they facilitate the energy transition by (1) mobilizing the public, (2) brokering between government and citizens, (3) providing context-specific knowledge and expertise, (4) initiating change and (5) proffering the integration of sustainability. Second, comparisons will be drawn based on differences in approaches amongst the cooperatives. Third, the results of the study will be used to identify several good practices for the governance of the energy transition through local renewable energy cooperatives.

The role of local renewable energy cooperatives for the facilitation of the energy transition can be distilled to five different key roles that these cooperatives provide based on their interactions with the public and members, the government, other cooperatives and the established energy sector. These activities are as follows: mobilizing the public, brokering between government and citizens, providing context-specific knowledge and expertise, initiating change and proffering the integration of sustainability. These roles reflect several key interactions of the governance dimensions represented in the conceptual framework. In the following section the specific roles will be explained in more detail.

\subsection{Mobilizing the Public}

The first governance role of cooperatives aligns with the interaction between the cooperative and its members which here reflects a wider scope based on the cooperatives' experiences extending further to the general public and prospective members as well. This role is the mobilizing of the public.

LRECs play a critical role in mobilizing citizens for the energy transition. Through various activities these cooperatives raise awareness and build support for the energy transition. Where a government tries to steer for a more renewable energy system through policies which often do not directly speak to citizens on an individual level, cooperatives attempt to mobilize people directly. Through personal advice, information days and public events at the local level, cooperatives promote the energy transition at a level that speaks directly to citizens.

A major asset for LRECs is that they provide the opportunity to participate on a voluntary basis. Whereas regulations will often require people to adopt sustainable practices because they have to, cooperatives offer this opportunity for people that want to become more sustainable. The key here is that people can choose for themselves if they want to participate and in how far they wish to participate. 
Both interviewed cooperatives believe that this voluntary approach is more effective at having people actively engage with sustainability than a commanding approach which often goes paired with a lot of citizen push-back.

Despite the potential for citizen mobilization, many cooperatives admit that it is only a small group of citizens that are actively involved within the cooperative while other members are only interested and do not actively participate. As a result, many of these cooperatives struggle with mobilizing these citizens and having them play an active role. On the other hand, there are plenty of examples where even a small number of active participants in a cooperative managed to mobilize vast amounts of resources and funding through a large group of members, according to the interviewed cooperatives. One such example is the success of Leudal Energie who gathered large amounts of funding for a wind turbine initiative [60]. While not all these members might be active participants, the cooperatives report that even association with renewable energy projects positively effects the member's attitude towards sustainability.

Therefore, it can be concluded that LRECs play a role in mobilizing citizens for the facilitation of the energy transition. While this role might seem trivial, it is not to be underestimated. Governments and private sector operators have attempted to mobilize citizens in an effort to promote renewable energy specifically and sustainability more generally. Successful mobilization is key for ensuring the energy transition, conventional efforts so far have only had limited success according to the cooperatives and scholars $[61,62]$.

\subsection{Brokering between Government and Citizens}

The second governance role for cooperatives reflects both the interactions that the cooperative has with the government as well as with its members. This role is that of broker between the government and citizen.

LRECs build bridges between citizens and the local government. The cooperatives indicated that they have a direct connection to their respective municipalities. There are regularly planned meetings between the members of the cooperative board and dedicated civil servants, the municipal council or the aldermen. Through these meetings the cooperative board can voice their opinion, plans and current activities but most importantly, represent the voice of their members who in turn represent the local community. This is especially effective if the cooperative is situated in small municipalities in rural areas where the cooperative members form a relatively larger portion of the population and the electorate and are therefore considered a serious voice and potential partner by the local government.

The cooperatives also function as broker by providing support for navigating government regulations and bureaucracies. While many citizens might want to conduct their own renewable energy projects (e.g., the instalment of a solar tracker or a small-scale solar farm on their property), they are often daunted by the associated regulatory requirements and the navigation off bureaucracies. This could hinder them in doing the project or even make them lose heart completely. In these specific cases, the cooperative can provide advice and help these initiators to realize their projects through its experiences as well as closer collaboration with municipal or regional government officials.

\subsection{Providing Context-Specific Knowledge and Expertise}

The third governance role of the cooperative spans all three interactions and constitutes the provision of context specific knowledge and expertise.

The LRECs play a key role in adapting the overall energy transition plan to a tangible and on local level. They do this not by stamping one blueprinted idea on every situation they find but by looking at the specific context of the situation, providing a targeted advice. As an example given by one of the interviewees: 'Some installers of solar panels attempt to convince people to invest in a set solar PV panels for their roof without first analysing the roof itself. This has resulted into new panels being installed on a roof that required extensive maintenance within the next two year period. This maintenance required the solar panels to be removed from the roof again, costing the homeowner 
a lot of money. This homeowner now has a negative view of solar panels and therefore sceptical of the renewable energy transition.' The cooperatives attempt to prevent these situations by looking at these specific circumstances such as the condition of the roof, before the advice of installing solar panels.

By providing this context specific knowledge and expertise, the cooperatives are able to provide better customized solutions. In general, this results in better attitudes of citizens towards sustainable technologies, a better strategy for achieving the sustainability goals and a more cost-effective method of facilitating the energy transition.

\subsection{Initiating Socially Accepted Change}

The fourth governance role for LRECs also works across all three interactions. This role is the initiation of accepted changes which cooperatives do through working with governments, other cooperatives as well as members and the public. Initiating socially accepted change differentiate LRECs from conventional command-and-control approaches towards the energy transition as it has a higher degree of social acceptance and perceived legitimacy. These conventional approaches are often only accepted on a limited basis by the public, however, LRECs often initiate projects for the energy transition that are accepted by the local population. As a cooperative member of Duurzaam Maasgouw stated 'if you tell people they have to do something they will often resist, however if you involve them and allow them to do things voluntarily, you get much more support and cooperation.' This involvement allows the cooperatives to initiate change that is socially accepted by local communities.

First, LRECs initiate change by kick-starting projects. The interviewed cooperatives noted that they create momentum for the energy transition by starting projects. The cooperatives look for and create opportunities within their local area for renewable energy projects. For example, by securing public rooftops for collective solar installations or by looking for suitable land for other renewable energy projects such as solar or wind farms. Even though some cooperatives indicated that they do not wish to exploit the projects themselves, they do provide concrete plans for local entrepreneurs, governments and project developers. The cooperatives have noted that if they provide plans that have been fully developed and researched in detail there is a big change these plans will become realized, 'if we go to the municipality with a fully developed plan they don't have to do much work themselves, thus, they will often continue with these sort of plans.' (Interviewee cooperative Duurzaam Roerdalen).

Second, LRECs work together in larger regional and national networks. Within these networks the cooperatives share knowledge, projects, successes and obstacles that they might be facing. This is not only relevant for the cooperatives themselves but it also allows the larger scale network organizations to represent a collective lobby of these energy cooperatives to push for change. For example, several cooperatives noted that they often run into bureaucratic rules which do not seem to fulfil any sort of function but hinder their ability to operate. Together with other cooperatives this issue was discussed during network meetings which resulted in the network pushing for changes in regulation. If this is successful the process for conducting the energy transition will be streamlined. Therefore, LRECs besides kick-starting energy projects also initiate policy change.

This initiating role where cooperatives provide fully developed plans for renewable energy projects are especially valuable if there is a lack of knowledge or incentive within the local area. In such a case the cooperative could present their plans to for example the municipality which may not have had the resources or dedicated civil servants to go through the development of such a plan. The cooperatives indicate that as long as the plans they provide are sound and developed in detail, municipalities are much more likely to follow-through and realize renewable energy projects that otherwise would have never been developed.

Third, LRECs foster local acceptance. This through offering people a voice in the development and running of renewable energy projects-as well as potential financial opportunities. LRECs are much more likely to generate local support than other parties. For example, large scale energy businesses might face a lot of resistance when attempting to create a new renewable energy project due to a lack of 
involvement and mutual mistrust [44]. The cooperatives believe that this resistance is mainly occurring because people only experience the negative externalities of these projects and cash flowing away from the region to large corporations. LRECs on the other hand strive to keep cash flows within the local community. When conducted in this way, the local population does not only suffer the negative effects of these projects but also get to share it is benefits. This inclusion of local citizens in energy projects leads to vastly different attitudes towards energy projects within one's vicinity, as noted by the cooperatives. They state that people could protest against the construction of a wind turbine while at the same time being extremely positive of the exact same turbine built in the exact same spot but (partially) funded by the citizens themselves. This suggests that cooperative initiatives are an effective tool against the dreaded 'Not in My Back Yard' NIMBY effects as discussed in Olsen [17].

\subsection{Proffering the Integration of Sustainability}

The fifth governance role of the energy cooperatives is the integration of broad perspective on sustainability going beyond the installation of more renewable energy capacity. This role reflects the interaction that the cooperatives have with both the government and their members.

Many of the cooperatives prefer to categorize themselves as a sustainability cooperative rather than just an energy cooperative. The idea of a sustainability cooperative is preferred as it represents a much broader view of what the cooperative considers the challenges ahead are and the potential solutions that it can employ to address those challenges. An interviewee stated that 'We prefer to think of ourselves as sustainability cooperatives as we want to do much more than just energy. It is true that energy is currently the most popular topic which attracts people but in the future we want to expand our focus.' (Interviewee cooperative Duurzaam Maasgouw). Where the main focus of the energy transition approach currently lies on a shift to renewables and direct energy saving measures, the cooperatives attempt to reflect a more integrated view on sustainability.

The cooperatives state that taking this more integrated view is a much better approach for ensuring sustainability and reaching the Sustainable Development Goals. According to the interviewed cooperatives, the idea that making the energy system sustainable is only about installing more renewable electricity generation capacity is a mistaken one. The cooperatives believe that it is not a realistic goal to build large amounts of renewable energy projects such as wind turbines and solar farms to provide electricity to only one municipality. Therefore, they pursue a more integrated form of sustainability in the hopes off achieving better results than those of the approach focused on by the established energy transition approach. They state that just because you can claim a certain amount of carbon credits for an energy initiative, does not mean that the project was sustainable and an effective contribution towards the 2050 goals.

The energy cooperative therefore certainly play a role in providing a more integrated view on sustainability for the facilitation of the energy transition. They go beyond what is required by regulation and subsidy requirements in the hope of working towards a more effective energy transition approach. In total the five different cooperative roles are: mobilizing the public, brokering between government and citizens, providing context specific knowledge and expertise, initiating accepted change and proffering the integration of sustainability. These roles are displayed in Figure 4. 


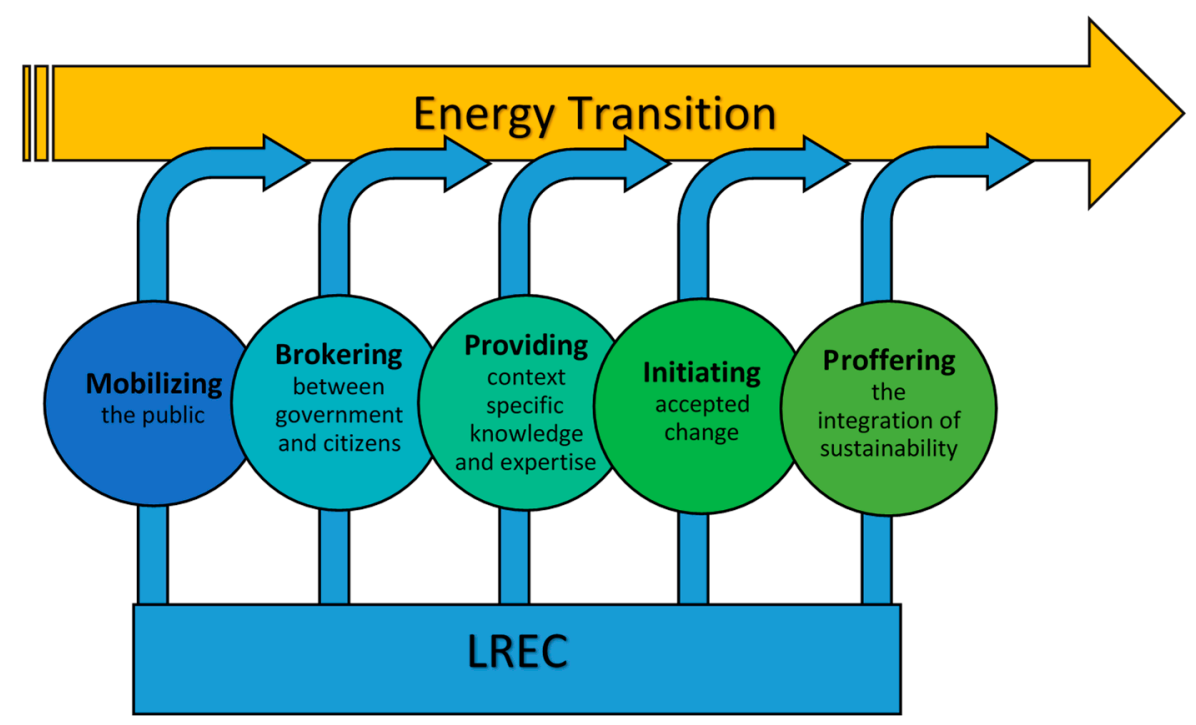

Figure 4. The five governance roles of LRECs for facilitating the energy transition (authors' own).

\section{Conclusions and Discussion}

This paper set out to inquire in which ways LRECs contribute to the renewable energy transition from a governance perspective. A conceptual framework is developed for analysing the governance roles that cooperatives play in the renewable energy transition. The framework is built around three key interactions shaping these governance roles, between (1) LRECs and their (potential) members, (2) LRECs and the government and (3) LRECs with other LRECs. Based on the survey and in-depth, semi-structured interviews in the province of Limburg, the Netherlands, five different roles for LRECs for facilitating the energy transition could be distilled. These indicated roles are: (1) mobilizing the public; (2) brokering between government and citizens; (3) providing context specific knowledge and expertise; (4) initiating accepted change; and (5) proffering the integration of sustainability. These five roles are a new addition to academic literature as the literature review did not reveal any peer-reviewed articles that attempted to identify the governance roles that LRECs fulfil in the energy transition.

Mobilizing the public is the first role, where cooperatives play a role in actively involving citizens for the energy transition. The second role is brokering between government and citizens, here cooperatives play a role in translating government policy to the citizen level for implementation. Simultaneously the cooperative acts as a representative of its members, voicing the citizens' opinions to the government. Third, providing context specific knowledge and expertise, here local energy cooperatives leverage their local embeddedness and personal approach towards facilitating the energy transition to provide context specific solutions. Fourth, initiating accepted change, here the energy cooperatives fulfil a role initiating projects within their communities. As the projects are initiated from the community and community members can have a say in how the project develops, there is a bigger chance that the project is accepted. This prevents any protest from within the community and builds support for a sustainable energy transition. And the last (fifth) role is proffering the integration of sustainability, here cooperatives take an active role is advocating for a more integrated sustainability approach towards the energy transition by focusing on factors beyond just energy generation.

Based on our empirical analysis, we distilled key factors for success for local energy cooperatives. First, they need to be locally embedded and try to be part of the community they are trying to serve. This provides the cooperative with unique knowledge, connections, as well as the goodwill of local citizens preventing potential NIMBY-effects [47]. A second success factor is that the cooperatives often have regular and direct communications with municipal or regional governments, this allows them to provide their insights and push for change at controlling government levels, this is especially important if the cooperatives manage to collaborate with the government to conduct sustainability projects. While regular collaboration with a municipality enables local small scale energy projects 
such as improvements of home insulations or small arrays of solar panels, collaboration with regional governments have the potential for larger projects such as wind-turbines or solar farms. The third success factor is honesty and transparency where the openness and honest trustworthy advice that the cooperatives try to provide earns them respect and trust from local citizens. The final success factor is related to this as it is non-commercial interests, whereas many other energy initiatives have a direct incentive to sell a certain product, the cooperatives try to steer away from these biases, leading to more citizen acceptance. While many cooperatives are focusing on small-scale projects, a small number of cooperatives such as Leudal Energie are working on major projects such as a wind farm, indicating the potential of cooperatives for contributing significantly to the energy transition. This success will be largely dependent on the cooperative's ability to mobilize citizens, government actors and resources resulting from these success factors and handling the following barriers.

Next to success factors the cooperatives also face certain barriers. The first one is mobilizing people, here the cooperatives indicated that is difficult to interest people in taking an active role in the cooperative and working towards the energy transition. Many people are interested but cannot find the time to actively participate. Resulting in cooperatives which mostly consist off and are run by pensioners. Thereby, excluding large sections of the population. A second barrier specifically limiting cooperative community energy projects is the lack of a dense grid network throughout most of the province of Limburg. This means that if a cooperative for example would like to start a solar farm, they will have to pay for the connection of that farm to the grid. As the network is not very dense in Limburg, such a connection might have to be very long and thus expensive. The final barrier for energy cooperatives is certain inhibiting regulations. The cooperatives indicated that there are certain regulations which do not seem to have a clear purpose but limit their ability to operate. An example of this is that cooperatives have to jump through several regulatory hoops in order to provide volunteers with a small compensation for their time or costs. Fortunately, the cooperatives work together in networks such as REScoop in an effort to change these regulations. However, these regulations inhibit their ability to facilitate the energy transition by diverting their attention and resources.

These success factors and barriers are a direct result of the empirical research conducted in this study. Therefore, these success factors and barriers reflect the specific context of the cooperative movement in Limburg. Studies within other regions might find additional success factors or barriers that could either complement in contrast those found in this thesis. A study conducted in the communities of Zschadraß and Nossen, Germany, by Musall \& Kuik [63] also concluded that the cooperative model indeed increases acceptance of renewable energy measures. This study however did not identify potential governance related barriers that could mitigate the success of cooperative energy initiatives.

Research conducted by Elzenga and Schwencke [38] did discuss the challenging relation between LRECs and local municipalities as both parties are still looking for their roles. However, their research did not consider this relation as part of the brokering process where the cooperatives represent the citizens in collective steering with municipalities. Our conclusion that this brokering roles takes place to the benefit of both parties aligns with the conclusions of Jonker et al. [45] who concluded that this collaboration affords municipalities and LRECs to take larger steps towards the energy transition.

Research conducted by Olsen [17] investigated a novel community energy typology, through analysis of several technical and social dimensions in Scotland. The results show that whilst the Scottish community energy sector contains a diverse range of motivations, technologies and social practices, the sector is dominated by groups who utilize local energy generation to achieve local socio-economic development, aligning with our conclusions for LRECs. Olsen also attempted to devise a typology of community energy initiatives. Her research had a broader perspective however with a more general focus on laws and regulatory forms. It did not focus specifically on a governance which this study does.

We conclude that based on our conducted research LRECs fulfil the following five governance roles regarding the facilitation of the energy transition: mobilizing the public, brokering between government and citizens, providing context specific knowledge and expertise, initiating accepted 
change and proffering the integration of sustainability. These roles were distilled from mixed method research containing of literature research, a survey and in-depth interviews in the province of Limburg, the Netherlands. The identified roles are a new addition to the academic literature.

We recommend that future research expands the research scope to include more cooperatives beyond the borders of Limburg. Additional participants will be necessary to develop a robust typology which distinguishes the LRECs based on certain governance criteria. Furthermore, as this study only investigated the perspective of the LRECs themselves, future research should investigate whether the identified governance dimensions in this paper are also recognized by other parties such as government institutions and the cooperative members. Finally, the discovered governance interactions and governance roles should be tested in other studies and fields to investigate their robustness regarding these interactions.

Author Contributions: Conceptualization, D.W. and C.S.; methodology, D.W., C.S. and V.V.; validation, D.W.; formal analysis, D.W.; investigation, D.W.; resources, D.W.; data curation, D.W.; writing—original draft preparation, D.W.; writing-review and editing, C.S. and V.V.; visualization, D.W.; supervision, C.S. and V.V.

Funding: The research presented in this paper received funding from the European Union's H2020 Research and Innovation program under grant agreement number 727642 ("ENERGISE"). The sole responsibility for the content of this paper lies with the authors.

Conflicts of Interest: The authors declare no conflict of interest.

\section{References}

1. Mey, F.; Hicks, J. Community Owned Renewable Energy: Enabling the Transition Towards Renewable Energy? In Decarbonising the Built Environment: Charting the Transition; Newton, P., Prasad, D., Sproul, A., White, S., Eds.; Springer: Singapore, 2019; pp. 65-82. [CrossRef]

2. Viardot, E. The role of cooperatives in overcoming the barriers to adoption of renewable energy. Energy Policy 2013, 63, 756-764. [CrossRef]

3. Proka, A.; Hisschemöller, M.; Loorbach, D. Transition without Conflict? Renewable Energy Initiatives in the Dutch Energy Transition. Sustainability 2018, 10, 1721. [CrossRef]

4. Van Veelen, B. Negotiating energy democracy in practice: Governance processes in community energy projects. Environ. Politics 2018, 27, 644-665. [CrossRef]

5. Heldeweg, M. Normative Alignment, Institutional Resilience and Shifts in Legal Governance of the Energy Transition. Sustainability 2017, 9, 1273. [CrossRef]

6. Hoicka, C.E.; MacArthur, J.L. From tip to toes: Mapping community energy models in Canada and New Zealand. Energy Policy 2018, 121, 162-174. [CrossRef]

7. Van Veelen, B. Making Sense of the Scottish Community Energy Sector-An Organising Typology. Scott. Geogr. J. 2017, 133, 1-20. [CrossRef]

8. Bauwens, T.; Gotchev, B.; Holstenkamp, L. What drives the development of community energy in Europe? The case of wind power cooperatives. Energy Res. Soc. Sci. 2016, 13, 136-147. [CrossRef]

9. Bauwens, T. Explaining the diversity of motivations behind community renewable energy. Energy Policy 2016, 93, 278-290. [CrossRef]

10. Holstenkamp, L.; Kahla, F. What are community energy companies trying to accomplish? An empirical investigation of investment motives in the German case. Energy Policy 2016, 97, 112-122. [CrossRef]

11. McCauley, D.; Heffron, R. Just transition: Integrating climate, energy and environmental justice. Energy Policy 2018, 119, 1-7. [CrossRef]

12. Walton, J.K. Revisiting the Rochdale Pioneers. Labour Hist. Rev. 2015, 80, 215-248. [CrossRef]

13. Hentschel, M.; Ketter, W.; Collins, J. Renewable energy cooperatives: Facilitating the energy transition at the Port of Rotterdam. Energy Policy 2018, 121, 61-69. [CrossRef]

14. Stephens, J.C. Energy Democracy: Redistributing Power to the People through Renewable Transformation. Environ. Sci. Policy Sustain. Dev. 2019, 61, 4-13. [CrossRef]

15. Schwencke, A.M. Lokale Energie Monitor 2018; Hier Opgewekt: Utrecht, The Netherlands, 2018. 
16. NOS. Drentse ondernemer windmolenpark krijgt bedreigingen en stopt. Available online: https://nos.nl/artikel/2277775-drentse-ondernemer-windmolenpark-krijgt-bedreigingen-en-stopt.html\# targetText=Drentse \%20ondernemer\%20windmolenpark\%20krijgt \%20bedreigingen \%20en \%20stopt,de $\%$ 20Drentse\%20Monden\%20en\%20Oostermoer (accessed on 7 March 2019).

17. Olsen, B.E. Renewable energy: Public acceptance and citizens' financial participation. In Elgar Encyclopedia of Environmental Law; Edward Elgar Publishing Limited: Cheltenham, UK, 2016; pp. 476-486.

18. European Union. Intended Nationally Determined Contribution of the EU and its Member States; NDC Registry: Berlin, Germany, 2015.

19. Hoppe, T.; de Vries, G. Social Innovation and the Energy Transition; Multidisciplinary Digital Publishing Institute: Basel, Switzerland, 2019.

20. Frieden, D.; Tuerk, A.; Roberts, J.; D'Hebermont, S.; Gubina, A. Collective Self-Consumption and Energy Communities: Overview of Emerging Regulatory Approaches in Europe. Available online: https://www.compile-project.eu/wp-content/uploads/COMPILE_Collective_self-consumption_EU_ review_june_2019_FINAL-1.pdf (accessed on 31 October 2019).

21. Servicepunt Energie Lokaal Limburg (SELL). Servicepunt Energie Lokaal Limburg. Available online: https://www.nmflimburg.nl/sell (accessed on 31 October 2019).

22. HIER Opgewekt. Ondersteuning Energiecoöperaties Per Provincie. Available online: https://www.hieropgewekt. nl/kennisdossiers/ondersteuning-energiecooperaties-per-provincie (accessed on 31 October 2019).

23. Geenen, H. Brief lokale energie coöperaties inzake ondersteuning SELL names lokale duurzame energie coöperaties in Limburg. Available online: https://www.nmflimburg.nl/brief-lokale-energie-coperaties-inzakeondersteuning-sell (accessed on 31 October 2019).

24. Upham, P.; Shackley, S. The case of a proposed 21.5 MWe biomass gasifier in Winkleigh, Devon: Implications for governance of renewable energy planning. Energy Policy 2006, 34, 2161-2172. [CrossRef]

25. Torfing, J.; Peters, B.G.; Pierre, J.; Sørensen, E. Interactive Governance: Advancing the Paradigm; Oxford University Press on Demand: New York, NY, USA, 2012.

26. Stoker, G. Governance as theory: Five propositions. Int. Soc. Sci. J. 2018, 68, 15-24. [CrossRef]

27. Meadowcroft, J. Who is in Charge here? Governance for Sustainable Development in a Complex World*. J. Environ. Policy Plan. 2007, 9, 299-314. [CrossRef]

28. Gray, D.E. Doing Research in the Real World; Sage: Thousand Oaks, CA, USA, 2013.

29. LaMarca, N. The Likert Scale: Advantages and Disadvantages. Field Res. Organ. Psychol. 2011, 1-3.

30. Longhurst, R. Interviews: In-Depth, Semi-Structured. In International Encyclopedia of Human Geography; Elsevier: Amsterdam, The Netherlands, 2009; pp. 580-584. [CrossRef]

31. Du Plessis, A. Public participation, good environmental governance and fulfilment of environmental rights. Potchefstroom Electron. Law J. Potchefstroomse Elektron. Regsblad 2008, 11, 1-34. [CrossRef]

32. Arnstein, S.R. A ladder of citizen participation. J. Am. Inst. Plan. 1969, 35, 216-224. [CrossRef]

33. International Co-operative Alliance [ICA]. Guidance Notes to the Co-operative Principles; International Co-operative Alliance: Brussels, Belgium, 2013.

34. Fairchild, D.; Weinrub, A. Energy Democracy. In The Community Resilience Reader; Springer: Heidelberg, Germany, 2017; pp. 195-206.

35. European Commission. A Framework Strategy for a Resilient Energy Union with a Forward-Looking Climate Change Policy; European Commission: Ispra, Italy, 2015.

36. REScoop MECISE. Mobilising European Citizens to Invest in Sustainable Energy-Clean Energy for All Europeans. Available online: https:/www.rescoop.eu/blog/mobilising-european-citizens-to-invest-insustainable-energy (accessed on 31 October 2019).

37. Burger, B. Net Public Electricity Generation in Germany in 2018; Fraunhofer Institute for Solar Energy Systems ISE: Freiburg im Breisgau, Germany, 2019.

38. Elzenga, H.; Schwencke, A.M. Lokale energiecoöperaties: Nieuwe spelers in de energie. Bestuurskunde 2015, 24, 17-26. [CrossRef]

39. Hermans, P.; Fens, T. Self-organisation in the residential electricity domain. 2013; 1-28, Unpublished work.

40. Bakker, M.D. New Energy Alliances; Exploring the Partnerships between Local Energy Cooperatives and Energy Companies in the Netherlands. Master' Thesis, Radboud Universiteit, Nijmegen, The Netherlands, 2016. 
41. Autoriteit Consument \& Markt. Vergunning Aanvragen Voor Het Leveren van Energie aan Kleinverbruikers. Available online: https://www.acm.nl/nl/onderwerpen/energie/energiebedrijven/vergunning-aanvragen-bij$\mathrm{acm} /$ (accessed on 31 October 2019).

42. Seyfang, G.; Park, J.J.; Smith, A. A thousand flowers blooming? An examination of community energy in the UK. Energy Policy 2013, 61, 977-989. [CrossRef]

43. Schwencke, A.M. Energieke bottomup in lage landen. Available online: http://asisearch.nl/wp-content/ uploads/2016/11/2012-ESSAY-Energieke-BottomUp-in-Lage-Landen-Schwencke-21082012-FINAL.pdf (accessed on 31 October 2019).

44. Walker, G.; Devine-Wright, P.; Hunter, S.; High, H.; Evans, B. Trust and community: Exploring the meanings, contexts and dynamics of community renewable energy. Energy Policy 2010, 38, 2655-2663. [CrossRef]

45. Jonker, F.; van Beek, J.; de Jong, E.; Brasser, A. De Energiecoöperatie als Samenwerkingspartner in de Gemeentelijke Energietransitie. Available online: https://www.hieropgewekt.nl/kennisdossiers/energiecooperatieals-samenwerkingspartner-in-gemeentelijke-energietransitie (accessed on 31 October 2019).

46. Van der Schoor, T.; Scholtens, B. Power to the people: Local community initiatives and the transition to sustainable energy. Renew. Sustain. Energy Rev. 2015, 43, 666-675. [CrossRef]

47. Devine-Wright, P. Beyond NIMBYism: Towards an integrated framework for understanding public perceptions of wind energy. Wind Energy 2005, 8, 125-139. [CrossRef]

48. Elzenga, H.; Schwencke, A.M. Energy Cooperatives: Aims, Operational Perspective and Interaction with Municipalities-The Energetic Society in Action; PBL Netherlands Environmental Assessment Agency: The Hague, The Netherlands, 2014.

49. REScoopNL. Over REScoopNL. Available online: http://www.rescoop.nl/over-rescoopnl/ (accessed on 24 May 2019).

50. Walker, G. What are the barriers and incentives for community-owned means of energy production and use? Energy Policy 2008, 36, 4401-4405. [CrossRef]

51. REScoop. The Energy Transition to Energy Democracy: Power to the People-Final Results Oriented Report of the Rescoop 20-20-20 Intelligent Energy Europe project; REScoop: Antwerp, Belgium, 2015.

52. Tanrisever, F.; Derinkuyu, K.; Jongen, G. Organization and functioning of liberalized electricity markets: An overview of the Dutch market. Renew. Sustain. Energy Rev. 2015, 51, 1363-1374. [CrossRef]

53. Parag, Y.; Sovacool, B.K. Electricity market design for the prosumer era. Nat. Energy 2016, 1, 16032. [CrossRef]

54. Boon, F.P. Local is Beautiful: The Emergence and Development of Local Renewable Energy Organisations. Master's Thesis, Utrecht University, Utrecht, The Netherlands, 2012.

55. HIER Opgewekt. Postcoderoosregeling-de Regeling in Het Kort. Available online: https://www.hieropgewekt.nl/ kennisdossiers/postcoderoosregeling-regeling-in-het-kort(accessedon24May2019). (accessed on 24 May 2019).

56. Janssen, M. The contribution of Local Energy Cooperatives to the Energy Transition in The Netherlands. Master's Thesis, Supervisor Radboud University, Nijmegen, The Netherlands, 2018.

57. Parnell, S. Defining a global urban development agenda. World Dev. 2016, 78, 529-540. [CrossRef]

58. Satterthwaite, D. Successful, safe and sustainable cities: Towards a New Urban Agenda. Commonw. J. Local Gov. 2016, 3-18. [CrossRef]

59. Hinton, P.R. Statistics Explained; Routledge: London, UK, 2014.

60. Leudal Energie. Windpark De Kookepan. Available online: https://leudalenergie.nl/windpark-de-kookepan (accessed on 31 October 2019).

61. Hoppe, T.; Graf, A.; Warbroek, B.; Lammers, I.; Lepping, I. Local Governments Supporting Local Energy Initiatives: Lessons from the Best Practices of Saerbeck (Germany) and Lochem (The Netherlands). Sustainability 2015, 7, 1900-1931. [CrossRef]

62. Hendriks, C.M. On Inclusion and Network Governance: The Democratic Disconnect of Dutch Energy Transitions. Public Adm. 2008, 86, 1009-1031. [CrossRef]

63. Musall, F.D.; Kuik, O. Local acceptance of renewable energy-A case study from southeast Germany. Energy Policy 2011, 39, 3252-3260. [CrossRef]

(C) 2019 by the authors. Licensee MDPI, Basel, Switzerland. This article is an open access article distributed under the terms and conditions of the Creative Commons Attribution (CC BY) license (http://creativecommons.org/licenses/by/4.0/). 